\title{
形状空間における平面超冗長マニピュレータの障害物回避手法
}

\author{
馬 書 根*1 紺 野 元 嗣*2
}

\section{An Obstacle Avoidance Scheme for Planar Hyper-Redundant Manipulators}

\author{
Shugen $\mathrm{Ma}^{* 1}$ and Mototsugu Konno*2
}

\begin{abstract}
Hyper-redundant manipulator has a very large or infinite degrees of kinematic redundancy, thus possesses some unconventional features such as the ability to enter a narrow space while avoiding obstacles. In this paper, we propose a new technique for a planar hyper-redundant manipulator to avoid the existing static obstacles in environment while performing a payload-location task from point to point. It is based on analysis in the defined posture space, where three parameters were used to determine the hyper-redundant manipulator configuration. The scheme is verified by computer simulation in case of using the model of the developed Hyper-R Arm. It shows that our method works perfect and the obstacles are well avoided globally.
\end{abstract}

Key Words: Hyper-redundant Manipulator, Real-time Posture Control, Posture Space, Obstacle Avoidance Control, Cell Decomposition

\section{1. まえがき}

本論文では, 多数の自由度を有する平面超冗長ロボット・マ ニピュレータのための障害物回避手法を提案し, 計算機シミュ レーションを用いてその有効性を検討する.

象の鼻のような多数の自由度を有する超冗長ロボット・マニ ピュレータは，そのて長な自由度を利用してアーム全体の姿勢 も制御できるため, 障害物を回避しやすく, アーム全体の運動 性能を改善しやすいなどの特異な機能を持っている。このよう なロボット・マニピュレータは, 原子炉内や化学プラント内な ど機器が錯綜する複雑な環境での検査・点検作業や, 高速道路 点検メンテナンス作業などにおいて有効である.

しかし，超圥長ロボット・マニピュレータを実現しょうとす る場合，いくつかの大きな技術的問題点が残されている。 その 一つは，通常の設計においてマニピュレータ本体の重量が過大 になってしまい可搬荷重が極端に小さくなってしまうことであ る (以後, 重量問題と呼ぶ). もう一つの問題点は超圥長自由 度に対する実時間制御の困難さである. 重量問題を解決するた め, ワイヤ干渉駆動型平面マニピュレータ機構が提案されてい る [1].この機構では, アクチュエータを基台部に設置するこ とでマニピュレータ本体を軽量化しており，さらにワイヤ間の 干涉駆動効果により大きな可搬荷重を出している。 また超圥長

原稿受付 1996 年 8 月 5 日

$* 1$ 茨城大学工学部

$* 2$ 茨城大学大学院

${ }^{* 1}$ Faculty of Engineering, Ibaraki University

${ }^{* 2}$ Graduate School, Ibaraki University
自由度の制御問題を解決するため, 運動学的圥長性を分解する 超冗長マニピュレータの姿勢制御手法が提案されている [3] [6]. この制御手法では, 超冗長マニピュレータ・アームを連続曲線 とみなしその先端位置を制御することで, 超冗長マニピュレー 夕の姿勢を実時間的に決定でき実時間制御を可能にしている. 筆者らはこのようなワイヤ干涉駆動機構と姿勢制御法を用いて, “Hyper-R Arm”と呼ぶ平面超圥長ロボット・マニピュレータ の開発を行っている [3].

本論文では, 平面超圥長マニピュレータが静的環境で作業す る場合, 作業空間にある障害物を実時間で回避できる手法を提 案する. 本手法は, 筆者らによって提案されている超圥長マニ ピュレータの姿勢制御法 [3] [6] をベースとし，後に定義される 「形状空間」において障害物回避軌道を生成して, 障害物の回 避制御を行う. 従来の手法と比較すると, 本手法は静的な環境 において, 平面超て長マニピュレー夕の実時間制御が可能であ るという利点を有する.そして本障害物回避手法の有効性を, 現在開発中の Hyper-R Arm をモデルとした計算機シミュレー ションで検証する.

\section{2. 超冗長マニピュレータの機構と制御法}

本章では, “Hyper-R Arm”と呼ばれる小型平面超圥長ロボッ ト・マニピュレータの機構およびそのための実時間姿勢制御法 を紹介する。

\section{1 超冗長マニピュレータの檴構}

Fig. 1 に示す Hyper-R Arm は 10 自由度を有する小型平面 超冗長多関節マニピュレータであり, 基台部に設置される 20 個 


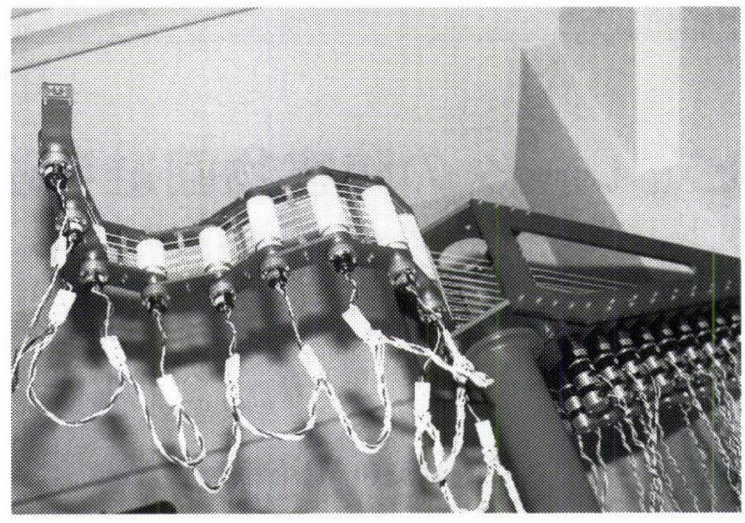

Fig. 1 Model of a hyper-redundant manipulator: Hyper-R Arm

のアクチュエータがワイヤを通じて各関節を干渉駆動している. この機構では, あるリンク $i$ を回転させるための一対のワイヤ は, リンク $i$ に固着されたプーリにその一端を固定され，関節 $i-1 \sim 1$ に回動自在に軸付けされたプーリに互いを逆向きに 巻架して, 土台部に至る. この機構は, ワイヤ $2 i-1$ を引張し て関節 $i$ にトルク $\tau_{i}$ を発生させると, 干渉駆動の効果で関節 $i-1 \sim 1$ においても同一トルク $\tau_{i}$ が発生する (同じプーリ半 径の場合)。このことから, 各関節において発生したトルクを 積極的に干渉させ合って, 必要とするワイヤ張力を小さくする ことができる。

試作した Hyper-R Arm の長さは $0.8[\mathrm{~m}]$, その全質量は $4.047[\mathrm{~kg}]$ である. 各関節に取り付けられるポテンショメータ で関節角を，モータに取り付けられている夕ゴジェネレータで 関節回転角速度を計測して，フィードバック制御系が構成され ている.

試作した Hyper-R Arm について, 基本機能実験を行った. その結果, 以下に述べるような特徵が明らかになった.

-可搬荷重：Hyper-R Arm の特徴の一つは干渉駆動効果に よって生じる大きな可搬荷重性能である.

- 作業範囲：試作した 10 自由度 Hyper-R Arm は, その超冗 長性を生かすことで, 広範囲な作業点に到達でき,また障害 物回避もしやすい.

・可変コンプライアンスアーム機構：一つの関節を 2 個のモー タで駆動する Hyper-R Arm は, アームのコンプライアンス をワイヤのバイアスカによって自由に調整でき, 作業に応じ て適切なコンプライアンスを設定することが可能である.

\section{2 超冗長マニピュレータの姿勢制御法}

圥長マニピュレータのための運動解析と動作計画方法として は, 従来擬似逆ヤコビ行列およびそのゼロ空間行列, または拡 張ヤコビ行列法を基にしている $[7] \sim[10]$. しかし，これらの方 法では, 行列演算において多くの処理時間を要し, 超冗長マニ ピュレータの実時間制御に利用することはできない。このよう な問題を解決するため, マニピュレータ・アームを連続曲線と 見なして運動解析を行う超冗長マニピュレー夕の姿勢決定法が 提案されている $[2] \sim[6]$. この制御法を現在開発中の Hyper-R Arm に適用した結果, 平面超圥長マニピュレータの実時間制御 が可能なことを確認した [3].
連続曲線を用いた姿勢制御法は, 超冗長マニピュレータの アーム形状を連続曲線とみなしたときの曲率関数 $\kappa(s)$ および 据率 $\tau(s)$ ( $s$ : Hyper-R Arm に沿う曲線長）に基ついている. アーム形状として用いられている曲線は多数ある. しかし, 議 論を限定した二次元平面上の運動においては, アームの曲線長 が一定でその先端座標を与えたときアームの姿勢を容易に求め ることができることから，サーペノイド曲線 [4]がよく用いら れる。サーペノイド曲線は,「曲率が曲線に沿って正弦波状に変 化する曲線」と定義され, その曲率 $\kappa(s)$ を次のように

$$
\kappa(s)^{\dagger}=\frac{2 \pi}{\ell} a_{1} \cos \left(\frac{2 \pi}{\ell} s\right)+\frac{2 \pi}{\ell} a_{2} \sin \left(\frac{2 \pi}{\ell} s\right)
$$

と表すことができる、ここで， $a_{1}, a_{2}$ は係数であり, $\ell$ はマニ ピュレータ・アームの全長である.この場合, 曲線長 $s$ における $x$ 軸方向との傾斜角 $\alpha(s)$, およびアーム先端座標 $(x(\ell), y(\ell))$ は,

$$
\begin{aligned}
\alpha(s) & =\alpha_{0}+\int_{0}^{s} \kappa(s) d s \\
& =\alpha_{0}+a_{1} \sin \frac{2 \pi}{\ell} s-a_{2} \cos \frac{2 \pi}{\ell} s+a_{2}, \\
x(\ell) & =\int_{0}^{\ell} \cos (\alpha(s)) d s \\
& =\cos \left(\alpha_{0}+a_{2}\right) J_{0}\left(\sqrt{a_{1}^{2}+a_{2}^{2}}\right) \ell, \\
y(\ell) & =\int_{0}^{\ell} \sin (\alpha(s)) d s \\
& =\sin \left(\alpha_{0}+a_{2}\right) J_{0}\left(\sqrt{a_{1}^{2}+a_{2}^{2}}\right) \ell
\end{aligned}
$$

のように求められる。ただし， $\alpha_{0}$ はアームの根元における曲 線の初期傾斜角, $J_{0}(x)$ は次数 0 の Bessel 関数である [11].

曲線（アーム）の先端座標が与えられるとき, それと初期傾 斜角 $\alpha_{0}$ から係数 $a_{1}, a_{2}$ が求められ, アーム姿勢関数の曲率 $\kappa(s)$ が誘導される.つまり, その係数 $a_{1}, a_{2}$ は, 式 (3) (4) の逆解を求めることにより,

$$
\begin{aligned}
& a_{2}=\tan ^{-1}\left(\frac{y(\ell)}{x(\ell)}\right)-\alpha_{0}, \\
& a_{1}=\left(\left[J_{0}^{-1}\left(\left(x(\ell)^{2}+y(\ell)^{2}\right)^{\frac{1}{2}} / \ell\right)\right]^{2}-a_{2}^{2}\right)^{\frac{1}{2}}
\end{aligned}
$$

と得られる.ここでは, $J_{0}^{-1}(x)$ は次数 0 の逆 Bessel 関数であ る [11]. 得られたこれらの係数を式 (2) に代入することによ り, 傾斜角関数を求めることができる.このとき, 平面超圥長 マニピュレータの関節角度は, 式 (2) から得られた傾斜角を 用いて

$$
\begin{aligned}
q_{1}= & \alpha\left(\frac{L}{2}\right)=a_{1} \sin \left(\frac{\pi}{N}\right)+a_{2}\left(1-\cos \left(\frac{\pi}{N}\right)\right)+\alpha_{0}, \\
q_{i}= & \alpha\left(\left(i-1+\frac{1}{2}\right) L\right)-\alpha\left(\left(i-1-\frac{1}{2}\right) L\right) \\
= & a_{1}\left[\sin \left(\frac{\pi}{N}(2 i-1)\right)-\sin \left(\frac{\pi}{N}(2 i-3)\right)\right] \quad(6) \\
& -a_{2}\left[\cos \left(\frac{\pi}{N}(2 i-1)\right)-\cos \left(\frac{\pi}{N}(2 i-3)\right)\right], \\
& \text { ただし, } \quad i=2,3, \cdots, N
\end{aligned}
$$

${ }^{\dagger} \kappa(s)=A \sin \left(\frac{2 \pi}{\ell} s+\phi\right) ; A=\frac{2 \pi}{\ell} \sqrt{a_{1}^{2}+a_{2}^{2}}, \phi=\tan ^{-1} \frac{a_{1}}{a_{2}}$ 
のように求められる。ここで, $N$ は関節数, $L(=\ell / N)$ はリン ク長である。

式（6）から分かるように，平面超圥長マニピュレータの姿 勢は 3 変数 $a_{1}, a_{2}, \alpha_{0}$ により決定される。 つまり，サーペノ イド曲線を用いて平面超穴長マニピュレータの姿勢を表す場合， その姿勢形状は 3 変数 $a_{1}, a_{2}, \alpha_{0}$ により決定される.

本章で述べた姿势制御法は簡単な式で構成されており，擬似 逆ヤコビ行列を使用した従来の手法と比較すると, 必要とする 演算時間が著しく減少している [3]. 結果として本手法は平面超 罙長マニピュレータの実時間姿勢制御を可能にしている.

以下では，本姿勢制御法を基本とする形状空間（Posture Space）を定義し，それを用いて障害物回避手法の提案を行う.

\section{3. 形状空間における障害物回避}

第 1 章で述べたように, 超圥長ロボット・マニピュレータは, その圥長な自由度を利用してアーム全体の姿勢も制御でき，作 業空間内に存在する障害物を回避しながら作業を行うことがで きる。

従来, 非㫕長マニピュレータの障害物回避計画については, 障害物回避軌道（OAT: Obstacle Avoidance Trajectory）を 直接に作業空間（Work space）で生成するもの [12]～[14]や 関節空間（Configuration space）で生成するもの[15] [16]など 多く提案されている。作業空間（Work space）における障害 物回避軌道の生成問題では, 人工ポテンシャル法 [13] が用いら れている。この手法では，ゴールへの吸引力を発生するポテン シャル関数と障害物からの反発力を発生するポテンシャル関数 の加重和を考え, 最急勾配降下法などの極值探索法を適用す ることにより OAT の生成を行う．人工ポテンシャル法の欠点 としては, 反発力と吸引力が釣り合う点が存在すると, ゴー ルへ到達することができずにデッドロックに落ちてしまうこと である。この問題を解決するため, 時間挙動を調節可能な人 エポテンシャル法 [14] が提案されている. しかし人工ポテン シャル法を㫕長マニピュレータに適用した場合, ゼロ空間べク トルを用いて極値の探索を行うため擬似逆行列およびゼロ空間 行列の計算に多く時間が費やされ，超圥長ロボット・マニピュ レー夕の実時間制御には適用できない。また作業環境中の障害 物とロボットが干渉しない動作（運動）を計画するために, 関 節空間（Configuration space）というモデルも提案されてい る [15] [16]. しかし，ロボットが多自由度（特に超午長ロボッ ト・マニピュレータの場合）であり，障害物およびロボットの 幾何学的な複雑さのため, 関節空間は複雑となり, その正確な 計算は現有の計算機では実現困難である.

従来の㫕長マニピュレータの OAT の生成手法のほとんどは, 作業空間における行列の解析（擬似逆行列およびゼロ空間行列） をべースにしている [17]〜 [20]. 実時間制御を考虑すると, こ れらの手法はそのまま超觉長マニピュレータの障害物回避制御 に適用できない，超圥長マニピュレータのための作業空間にお ける運動解析に基づく障害物回避手法が提案されている [5]. し かしこの手法では障害物回避軌道が自動的に生成されるのでは なく，操縦者が入力するものになっている，そこで本論文では, 後に定義する形状空間で運動解析を行い, 新しい障害物回避手
法を提案する.

ここでまず，平面超冗長マニピュレータの実時間制御のため の, “形状空間”を定義しておく. 前章で述べたように, 平面超 圥長マニピュレータの姿勢形状は, 3 変数 $\left(a_{1}, a_{2}, \alpha_{0}\right)$ によ り決定される (式 (6) を参照). よって, 平面超冗長マニピュ レータの形状空間を次のように定義することができる。

定義：平面超圥長マニピュレータのアーム姿勢をサー ペノイド曲線と見なして制御される場合, 作業空間 におけるその姿势を、アーム曲線形状パラメー夕æ $\left(a_{1}, a_{2}, \alpha_{0}\right)$ によって表すことができる.このとき， 平面超冗長マニピュレータで実現可能な姿勢形状の

集合を形状空間（Posture Space）巴 と定義する。 形状空間での運動解析に基づいて, 平面超圥長マニピュレー 夕が作業空間にある静的障害物を回避するアルコリズムは以下 の手順になると考えられる。

i）平面超冗長マニピュレータの作業空間および作業空間にあ る障害物を形状空間 ほ にマッピングする；

ii）形状空間での運動解析を行い，障害物回避軌道 OAT を生 成する；

iii）生成されたすべての OAT のなかから最短距鹤となるもの を見つけ出す；

iv）静的障害物のある作業空間において障害物回避駆動制御を 行う.

本論文で提案する手法のアルゴリズムは, 平面超圥長マニピュ レータの作業空間および作業空間にある障害物の形状空間への マッピング処理と障害物回避軌道の生成・追従制御を別々にす ることが可能であり，作業空間から形状空間へのマッピングを Off-line で行い, 障害物回避軌道の生成・追従制御を On-line で行う. 静的な摆境において, On-line で作業空間から形状空 間へのマッピングを実行する必要性がなく, 時間のかかるこの 処理を Off-line で行うことが可能である.このため, マッピン グされた形状空間で演算時間のかからない障害物回避軌道の生 成・追従制御を実時間で行うことができる，次に以上の手順を 順に議論していく.

\section{1 形状空間への障害物のマッピング}

平面超圥長マニピュレータの形状空間 $₫$ は, マニピュレー 夕のアーム姿勢を表す変数 $a_{1} ， a_{2} ， \alpha_{0}$ で表されている，そこ で，それぞれの変数が取りうる範囲（これを可動範囲とする） において変数 $a_{1}, a_{2}, \alpha_{0}$ を任意に変化させ，障害物と衝突す るときの值を形状空間に記述することにより形状空間へ障害物 のマッピングを行うことができる.

Fig. 2 に示す作業空間（デカルト座標空間）上の障害物を形 状空間にマッピングしたものを Fig. 3 に示している. Fig. 3 に 示した障害物データは，セル化（標本化）[21][22]を行った後 のものである. 元の連続データをセル化することにより，OAT の生成が容易になる．本論文では，このセル化したデータを用 いて形状空間中での OAT の生成を行う.

3.2 形状空间における障害物回避軌道生成アルゴリズム 三次元形状空間で OAT の生成は一般的に極めて難しい。こ こではまず二次元形状空間（平面）における障害物回避につい て議論し，それを三次元形状空間に拡張していく. 


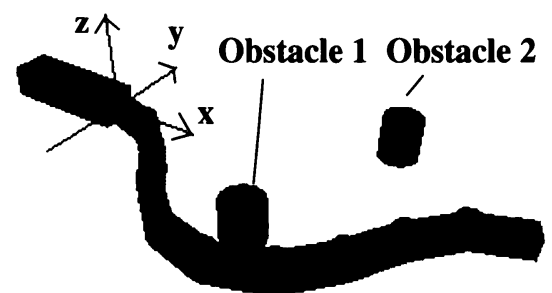

Fig. 2 A hyper-redundant manipulator in the workspace where the static obstacles exist

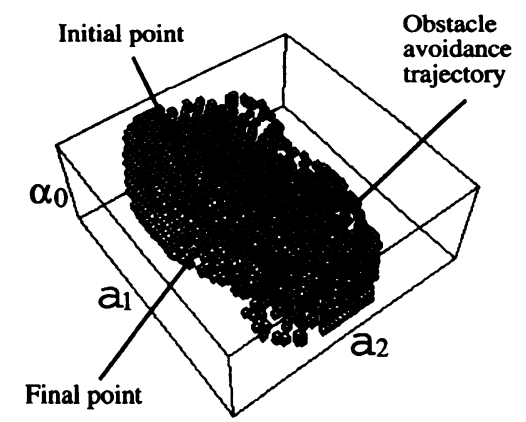

Fig. 3 Obstacles in the posture space, mapped from the obstacles in workspace shown in figure 2 , and the obstacle avoidance trajectory in the posture space

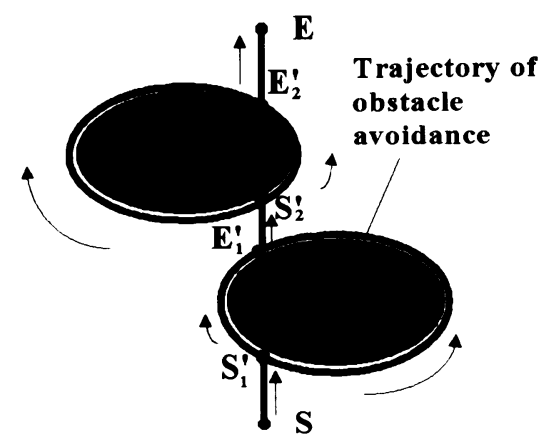

Fig. 4 2-D obstacle avoidance trajectories in the case of two obstacles

\section{2 .1 二次元形状空間での障害物回避アルゴリズム}

平面問題において, Fig. 4 に示すような障害物が形状空間に 存在する場合, 二次元形状空間における障害物回避軌道 OAT を生成するアルゴリズムを以下に示す。

1) 軌道始点 $\mathbf{S}$ (初期アーム姿势) 加軌道終点 $\mathbf{E}$ (終端 アーム姿势）までの直線を引き，障害物 $i$ との交点 $\mathbf{S}_{i}^{\prime}$, $\mathbf{E}_{i}^{\prime}(i=1, \cdots, K ; K$ : 障害物の数) のすべてを見つけ出す;

2) それぞれの障害物において, $\mathbf{S}_{i}^{\prime}$ と $\mathbf{E}_{i}^{\prime}$ を結ぶ二つの輪郭を 求める;

3）おのおのの部分軌道を連結 $\left(\mathbf{S}-\mathbf{S}_{1}^{\prime}-\mathbf{E}_{1}^{\prime}-\cdots-\mathbf{S}_{K}^{\prime}-\right.$ $\left.\mathbf{E}_{K}^{\prime}-\mathbf{E}\right)$ し， $2^{K}$ 個の OAT を生成する；

4) $2^{K}$ 個の軌道から最短距離のものを一つ選択する.

3.2 .2 三次元形状空間での障害物回避アルゴリズム 単純な形状の障害物である場合, 二次元形状空間の場合と同 じような OAT 生成アルゴリズムが使用可能である。しかし，

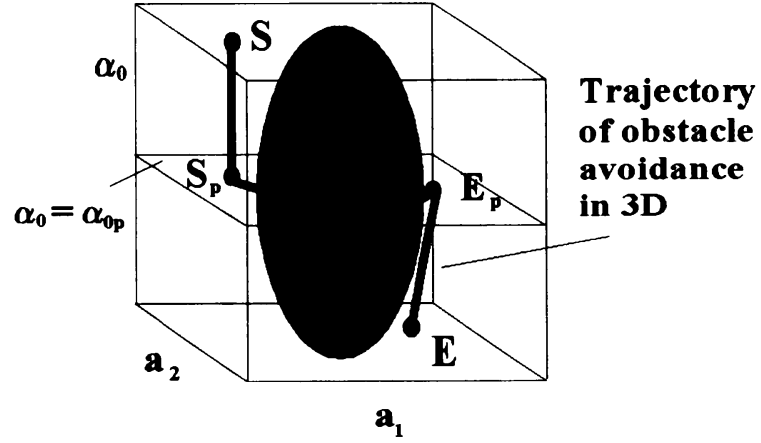

Fig. 5 3-D obstacle avoidance trajectories

障害物形状がいつも単純とは限らず，二次元形状空間における OAT 生成アルゴリズムがそのまま適用できない場合もある。こ こでは, 三次元形状空間での OAT を生成するアルゴリズムに ついて述べる。まず, 三次元形状空間での始点 $\mathbf{S}$ の座標（初 期アーム姿勢を表す形状パラメー夕）を $\left(a_{1}^{s}, a_{2}^{s}, \alpha_{0}^{s}\right)$ とし, 終 点 $\mathbf{E}$ (終端アーム姿势を表す形状パラメー夕) を $\left(a_{1}^{e}, a_{2}^{e}, \alpha_{0}^{e}\right)$, なお平面 $\alpha_{0 p}$ における始点と終点の投影点 $\mathbf{S}_{p}, \mathbf{E}_{p}$ の座標をそ れぞれ $\left(a_{1 p}^{s}, a_{2 p}^{s}, \alpha_{0 p}^{s}\right),\left(a_{1 p}^{e}, a_{2 p}^{e}, \alpha_{0 p}^{e}\right)$ としておく.

1) 始点 $\mathbf{S}$ と終点 $\mathbf{E}$ を任意の平面 $\alpha_{0}=\alpha_{0 p}$ において投影し, おのおのの投影点 $\mathbf{S}_{p}, \mathbf{E}_{p}$ を求める;

（投影点が障害物内部にあるならば，そこから一番近い障 害物輪郭上の点を見つけ出し，それを投影点とみなす.）

2) 二次元形状空間での OAT 生成アルゴリズムを用いて，平 面 $\alpha_{0}=\alpha_{0 p}$ における OAT を生成する;

3）始点 $\mathbf{S}$ から $\mathbf{S}_{p}, \mathbf{E}_{p}$ から終点 $\mathbf{E}$ 一直線的にスライドし, おのおのの間で OAT を生成する;

(この過程において OAT 点が障害物内部に入ってしまう 場合は, 一番近い障害物輪郭上の点を見つけ, シフトして いく.)

4) 得られた軌道をおのおの連結し, 三次元形状空間での OAT とする

この三次元形状空間での OAT 生成アルゴリズムは，任意の 平面 $\alpha_{0}=\alpha_{0 p}$ において二次元形状空間での OAT が存在する 場合にのみ有効である。

\section{3 障害物回避軌道の漼最息化}

前述のアルゴリズムで生成された形状空間での OAT は, 部 分的には障害物の輪郭に沿ったものであり，大きな意味で最短 距離軌道とはいえない。そこで，以上で得られた OATを擬似 的に最短化†する方法を示す。

まず, Fig.6(a)のようにOAT が得られているものと仮定 する.このとき擬似最短 OAT は, 障害物と接線で交わる障害 物輪郭上の点を見つけ, 軌道のおのおのの部分（接線および障 害物の輪郭）を連結することにより容易に得ることができる. Fig.6 (b) はその例を示している. また,この方法は, 複雑な二

\footnotetext{
†形状空間上の最短化軌道は，作業空間上の最短軌道でもなく，消費工 ネルギーを最小にしたものでもない，本論文で，静的な作業桭境に存 在する障害物を実時間で回避することを竓論の中心においた．消費エ ネルギーを最小化する障害物回避制御などについては別報で論じる。
} 


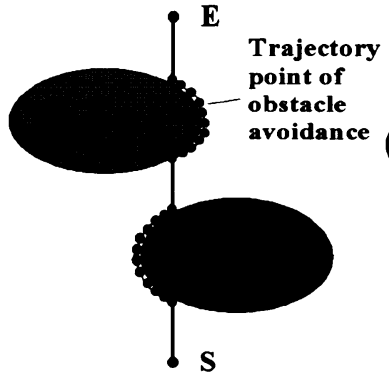

(a) Before optimization

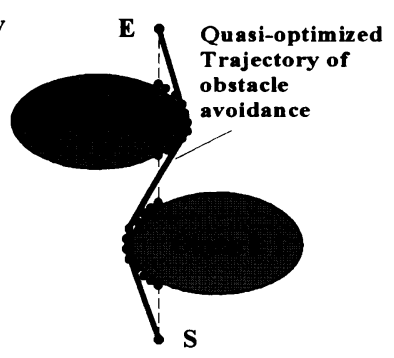

(b) After optimization
Fig. 6 Obstacle avoidance trajectories in the posture space

次元形状空間での場合だけでなく, 三次元形状空間の場合にお いても使用可能である.

形状空間で OATが得られた後, 関節空間における OATは式 （6）から簡単に生成することができ，作業空間における OAT も式（3）(4) 加容易に求められる.

\section{4. 計算機シミュレーション}

Fig. 1 に示した平面超冗長マニピュレータ Hyper-R Arm を モデルとして，提案した OAT 生成アルゴリズムによる計算 機シミュレーションを行った. Fig. 2 に示したモデルの各リン

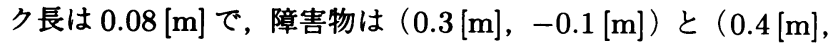
0.2 [m]）を中心とする半径 $0.05[\mathrm{~m}]$ の二つの円盤である.

Fig. 3 は形状空間における障害物と障害物回避軌道 (OAT) を示している.ここでは, $-2.0<a_{1}, a_{2}<2.0,-1.571[\mathrm{rad}]<$ $\alpha_{0}<1.571[\mathrm{rad}]$ の間において, $\delta a_{1}=\delta a_{2}=0.04$ と $\delta \alpha_{0}=0.087[\mathrm{rad}]$ の散散值でセル化した。また，障害物の 形状を明確にするため, $\alpha_{0}=0.0[\mathrm{rad}], \alpha_{0}=0.698[\mathrm{rad}]$, $\alpha_{0}=0.785[\mathrm{rad}]$ の場合における $\left(a_{1}, a_{2}\right)$ 平面デー夕を Fig. 7 に示す.

Fig. 3 に示す軌道を作業空間において実行すると, Fig. 8 (b) のようになる，比較のために，障害物回避アルゴリズムを使用 しない場合のマニピュレータ姿勢の変化を Fig. 8 (a) に示す. 結 果として，本論文で提案した障害物回避アルゴリズムは静的な 環境での障害物を確実に回避することができるということが分 かる.

最後に, 本論文の手法で障害物回避を行う過程において費 やした計算時間を述べおく．NEC PC-9821Bp（486DX2$66[\mathrm{MHz}]$ ）を用いた場合，障害物の作業空間から形状空間へ のマッピングに約 15 分, その障害物データのセル化に約 5 分 かかった，そして擬似最短化 OAT の生成は 0.36 秒であった。 OAT を得た後，その軌道を追跡するマニピュレータの制御は約 0.21 秒で行うことができた．静的な環境において，障害物の形 状空間へのマッピンク, データのセル化は前もって Off-line で 行い, 平面超㫕長マニピュレータの擬似最短化 OAT の生成と 軌道追跡制御は On-line 制御で行うことから, 実時間制御が可 能である。このことは，筆者らが開発中の平面超圥長マニピュ レータ実機モデル（Hyper-R Arm）に Fig. 8 (b)に示す障害物 回避軌道を追跡させる実機実験からも確認されている。

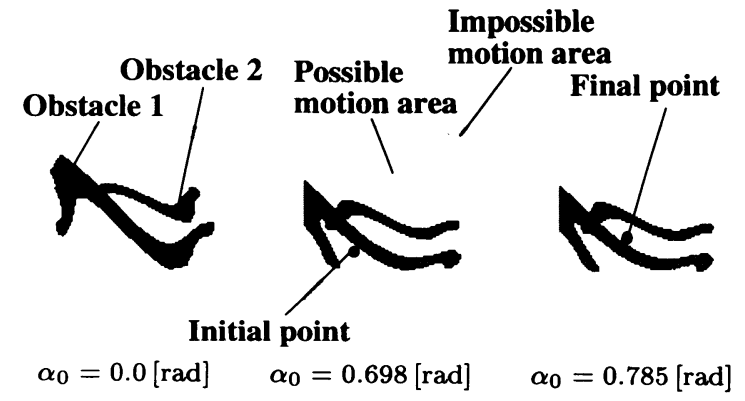

Fig. 7 Examples of the obstacles on the some $\left(a_{1}, a_{2}\right)$ planes

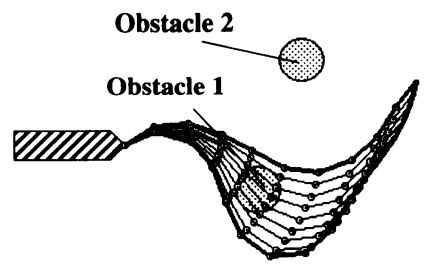

(a) Without obstacle avoidance scheme

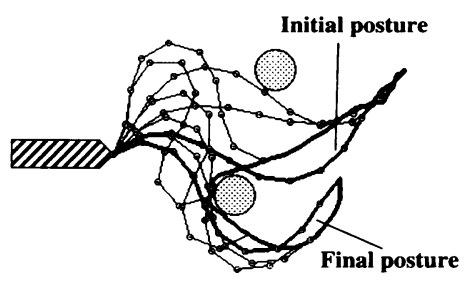

(b) With obstacle avoidance scheme

Fig. 8 Resulted manipulator postures in workspace

\section{5. 結論および今後の課題}

本論文では, 多数の自由度を有する平面超冗長ロボット・マニ ピュレータのための障害物回避手法を提案した，本手法は，筆 者らによって提案されている超冗長マニピュレー夕の姿勢制御 法に基づいて，新たに定義した「形状空間（Posture Space）」 での解析を行い, この空間内での障害物回避軌道を生成する. 計算機シミュレーションを用いて，その有効性も確認した。本 手法は, コストが安く計算能力も高くない計算機で構築された 超冗長マニピュレータの制御システムのみに有効である。しか し, 本手法により実時間制御が可能であるが, 超圥長マニピュ レータのアームを連続曲線上に拘束した姿勢制御に基づいたた めマニピュレータの可動範囲が減少している，さらに最適化に 使用できる自由度も少なくなっている，更なる最適化と可動範 囲を必要とする作業を実現する制御システムには，高価・高性 能な計算機を利用し，行列などの計算を用いた最適化制御が有 効であると思われる。

本論文において, 平面超圥長ロボット・マニピュレータのみ を限定し, 障害物回避問題を論じた. しかし, 本論文で検討し た障害物回避手法は, Fig.9 に示す平面超冗長ロボット・マニ ピュレータの実際的な応用例に対してそのまま応用でき，実用 上重要である。なお, 本論文では, 平面超笛長マニピュレー夕 が障害物を実時間で回避することを議論の中心においた。しか 


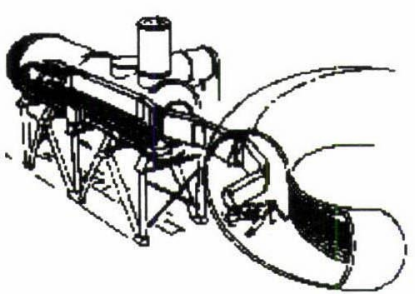

(a) Maintenance robot for nuclear reactor

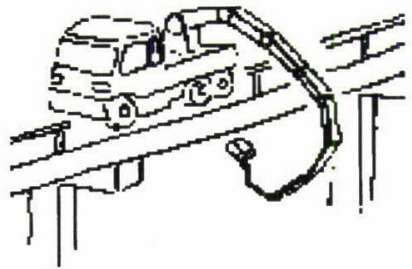

(b) Maintenance robot for highway and/or freeway

Fig. 9 Application examples of the 2D hyper-redundant manipulator

し第 3 章で述べた最短距離軌道はエネルギー消費などの観点 から見ると必ずしも最適ではない場合がある、今後の課題とし ては,

・ 三次元空間における超圥長ロボット・マニピュレータの障害 物回避問題についての検討；

・消費エネルギーなどを考虑する障害物回避手法の検討 などがあげられる。

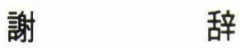

本論文に対して，日本語の校正をしていただいた茨城大学工 学部システム工学科近藤久助手に感謝します。なお，本論文の 一部は文部省科学研究費補助金 No.07750281 の援助を受けた.

\section{参 考 文 献}

[1] S. Hirose and S. Ma: "Coupled tendon-driven multijoint manipulator," Proc. 1991 IEEE Int. Conf. on Robotics and Automation, vol.2, pp.1268-1275, Sacramento, CA, 1991.

[2] 馬, 広瀬, 横島：“多関節マニピュレータのための 2 自由度慣性モレ イ駆動”, 日本ロボット学会誌, vol.14, no.3, pp.436-443, 1996.

[3] 馬, 紺野, 吉灘, 堤: “超冗長ロボット・マニピュレータの開発”, ロボ ティクス・メカトロニクス講演会'95 講演論文集, vol.B, pp.760-763, 1995.

[4] S. Hirose: "Biologically Inspired Robots," Oxford, Oxford University Press, 1993.

[5] G.S. Chirikjian and J.W. Burdick: "An obstacle avoidance algorithm for hyper-redundant manipulators," Proc. 1990 IEEE Int. Conf. on Robotics and Automation, vol.1, pp.625-631,
Cincinnati, OH, 1990.

[6] S. Ma, S. Hirose and H. Yoshinada: "Development of a hyperredundant manipulator for maintenance of nuclear reactors," Int. J. of Advanced Robotics, vol.9, no.3, pp.281-300, 1995.

[7] C.A. Klein and C.H. Huang: "Review of the pseudoinverse for control of kinematically redundant manipulators," IEEE Trans. on Syst., Man, Cyber., vol.13, no.2, pp.245-250, 1983.

[8] T. Shamir and Y. Yomdin: "Repeatability of redundant manipulators: Mathematical solution of the problem," IEEE Trans. on Automatic Control, vol.33, no.11, pp.1004-1009, 1988.

[9] A. Liegeois: "Automatic supervisory control of the configuration and behavior of multi-body mechanisms," IEEE Trans. on Syst., Man, Cyber., vol.7, no.12, pp.868-871, 1977.

[10] J. Baillieul: "Kinematic programming alternatives for redundant manipulators," Proc. 1985 IEEE Int. Conf. on Robotics and Automation, vol.2, St. Louis, MO, 1985.

[11] I.N. Sneddon: "Special Functions of Mathematical - Physics and Chemistry," London: Oliver \& Boyd, 1961.

[12] 尾崎, 毛利, 高田：“マニピュレータの占有空間を考虑した障害物回避 動作の決定法”，計測自動制御学会論文集，vol.18, no.9, pp.72-79, 1982

[13] O. Khatib: "Real-time obstacle avoidance for manipulators and mobile robots," Int. J. of Robotics Research, vol.5, no.1, pp. $90-98,1986$.

[14] 辻, Morasso, 重橋, 金子: “収束時間を調整可能な人工ポテンシャル 法によるマニピュレータの動作計画”, 日本ロボット学会誌, vol.13, no.2, pp.285-290, 1995.

[15] T. Lozano-Perez: "Spatial planning: A configuration space approach," IEEE Trans. on Computers, vol.32, no.2, pp.108-120, 1983.

[16] T. Lozano-Perez: "A simple motion-planning algorithm for general robot manipulators," IEEE Trans. on Robotics and Automation, vol.3, no.3, pp.224-238, 1987.

[17] M. Kircanski and M. Vukobratovic: "Contribution to control of redundant robotic manipulators in an environment with obstacles," Int. J. of Robotics Research, vol.5, no.4, pp.112-123, 1986

[18] Y. Nakamura, H. Hanafusa and T. Yoshikawa: "Task-priority based on redundancy control of robot manipulators," Int. J. of Robotics Research, vol.6, no.2, pp.3-15, 1987.

[19] H. Zghal, R.V. Dubey and J.A. Euler: "Collision avoidance of a multiple degree of redundancy manipulator operating through a window," ASME Trans. on Dyn. Syst., Meas. Control, vol.114, pp.717-720, 1992.

[20] R.V. Mayorga, F. Janabi-Sharifi and A.K.C. Wong: "A fast approach for the robust trajectory planning of redundant manipulators," J. of Robotic Systems, vol.12, no.2, pp.147-161, 1995.

[21] 劉，音田：“干涉チェックを行なわない配置空間近似表現の作成手法”, 計測自動制御学会論文集, vol.31, no.1, pp.89-97, 1995 .

[22] C. Marolo and E. Pagello: "A cell decomposition approach to motion planning based on collision detection," Proc. 1995 Int Conf. on Advanced Robotics, vol.1, pp.481-488, Sant Feliu, Spain, 1995.

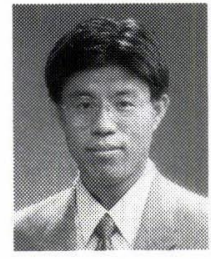

馬 書根 (Shugen Ma)

1963 年 8 月 10 日生. 1991 年東京工業大学大学院 機械物理専攻博士課程修了. 工学博士. 同年 (株) 小松製作所研究本部勤務. 1993 年茨城大学工学部 講師, 1996 年助教授, 現在に至る。この間, 1992 年 4 月から 1 年間米国カリフォルニア大学客員研 究員、ロボットの機構と制御の研究に従事. 1992 年計測自動制御学会論文賞受賞. 計測自動制御学会, 日本機械学会, IEEE 各会員.
(日本ロボット学会正会員)

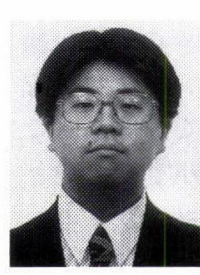

紺野元嗣 (Mototsugu Konno)

1973 年 3 月 20 日生. 1995 年茨城大学工学部 ステム工学科卒業. 同年, 同大学大学院理工学研 究科博士前期課程に進学, 現在に至る. 超圥長口 ボット・マニピュレータの機構と制御の研究に従 事.

（日本ロボット学会学生会員） 